\title{
Effects of exposure to 5-MeO-DIPT during adolescence on brain neurotransmission and neurotoxicity in adult rats
}

\author{
Karolina Noworyta-Sokołowska' ${ }^{1}$ Katarzyna Kamińska ${ }^{1} \cdot$ Joanna Rzemieniec ${ }^{2} \cdot$ Agnieszka Wnuk $^{2}$. \\ Jakub Wojcieszak ${ }^{3}$ - Anna Maria Górska ${ }^{1}$ - Grzegorz Kreiner ${ }^{4} \cdot$ Małgorzata Kajta $^{2} \cdot$ Krystyna Gołembiowska $^{1}$
}

Received: 9 May 2018 / Accepted: 4 July 2018 / Published online: 19 July 2018

(c) The Author(s) 2018

\begin{abstract}
Purpose Tryptamine hallucinogen 5-methoxy- $N, N$-diisopropyltryptamine (5-MeO-DIPT) is a serotonin transporter inhibitor with high affinity for serotonin $5-\mathrm{HT}_{1 \mathrm{~A}}$ and $5-\mathrm{HT}_{2 \mathrm{~A} / \mathrm{C}}$ receptors. We showed previously that 5-MeO-DIPT in a single dose increased neurotransmitter release in brain regions of rats and elicited single- and double-strand DNA breaks. Herein we investigated the effects of repeated-intermittent 5-MeO-DIPT administration in adolescence on dopamine (DA), serotonin (5-HT) and glutamate release in brain regions of adult rats. Furthermore, we examined caspase-3 activity, oxidative DNA damage, the Gpx3, Sodl, Htla and Ht2a mRNA expression levels, and cell viability.

Methods Neurotransmitter release was measured by microdialysis in freely moving animals. Caspase-3 activity was assessed colorimetrically, and oxidative DNA damage with the comet assay, while the Gpx3, Sodl, Htla and Ht2a mRNA expression levels were assessed by real-time polymerase chain reaction. Cell viability was studied in SH-SY5Y and Hep G2 cells by the MTT test.

Results We observed changed responses of DA, 5-HT and glutamate neurons to a challenge dose of 5-MeO-DIPT when animals were treated repeatedly in adolescence with this hallucinogen. The basal extracellular levels of DA and 5-HT were decreased in the striatum and nucleus accumbens, while glutamate level was increased in the nucleus accumbens and frontal cortex. The damage of cortical DNA, increased Gpx3 and Sod1 mRNA expression and affected caspase-3 activity were also observed. Furthermore, decreased Htla and Ht2a mRNA expression in the frontal cortex and marked cytotoxicity of 5-MeO-DIPT were found.

Conclusions These results suggest that 5-MeO-DIPT given repeatedly during adolescence affects brain neurotransmission and shows neurotoxic potential observed in adult animals.
\end{abstract}

Keywords 5-MeO-DIPT $\cdot$ Exposure in adolescence $\cdot$ Neurotransmitter release $\cdot$ Dopamine, serotonin and glutamate $\cdot$ DNA damage $\cdot$ Cytotoxicity

Krystyna Gołembiowska

nfgolemb@cyf-kr.edu.pl

1 Department of Pharmacology, Institute of Pharmacology, Polish Academy of Sciences, 12 Smętna, 31-343 Kraków, Poland

2 Department of Experimental Neuroendocrinology, Institute of Pharmacology, Polish Academy of Sciences, 12 Smętna, 31-343 Kraków, Poland

3 Department of Pharmacodynamics, Medical University of Łódź, Muszyńskiego 1, 90-151 Łódź, Poland

4 Department of Brain Biochemistry, Institute of Pharmacology, Polish Academy of Sciences, 12 Smętna, 31-343 Kraków, Poland

\section{Introduction}

5-Methoxy- $N, N$-diisopropyltryptamine (5-MeO-DIPT) synthesized by Shulgin and Carter [1] is a tryptamine hallucinogen with a street name "foxy" or "foxy methoxy". As a substitute for MDMA, 5-MeO-DIPT has been permanently controlled in the USA as a schedule I substance under the Controlled Substances Act (69 FR 58050) [2, 3].

$5-\mathrm{MeO}-\mathrm{DIPT}$ is a competitive serotonin transporter (SERT) inhibitor and has a lower affinity for dopamine transporter (DAT) [4]. The hallucinogenic activity of 5-MeODIPT shown in mice was caused by the stimulation of postsynaptic 5- $\mathrm{HT}_{2 \mathrm{~A}}$ receptors [5]. Moreover, 5-MeO-DIPT had also in vitro high affinity for $5-\mathrm{HT}_{1 \mathrm{~A}}$ and $5-\mathrm{HT}_{2 \mathrm{C}}$ receptors 
[5, 6]. High concentrations of 5-MeO-DIPT produced a marked cytotoxicity assessed by a cell viability assay in COS-7 cells [3]. Chronic 5-MeO-DIPT administration decreased 5-HT levels in the rat prefrontal cortex, striatum and hippocampus [7-9], which may suggest its neurotoxicity. Clinical data indicated potent multi-organ effects of 5-MeO-DIPT as the users experienced euphoria, disinhibition, increased sociability, and visual and auditory hallucinations, but also effects like mioclonus, restlessness, insomnia, anxiety, nausea, vomiting and diarrhea [10]. According to the Drug Enforcement Administration (DEA), the doses used by human subjects range from 6 to $20 \mathrm{mg}$ with the duration of symptoms for approximately $6 \mathrm{~h}$ [2]. The threshold dose for hallucinogenic activity was $4 \mathrm{mg}$ with an effective range from 6 to $10 \mathrm{mg}$ [11]. Our earlier microdialysis study in rats showed that 5-MeO-DIPT in a wide range of doses $(5,10$ and $20 \mathrm{mg} / \mathrm{kg})$ increased extracellular levels of dopamine (DA), serotonin (5-HT) and glutamate with different potencies among brain regions [12]. The decrease in DA, 3,4-dihydroxyphenylacetic acid (DOPAC) and homovanilic acid (HVA) tissue contents as well as DNA damage also suggested the neurotoxicity of 5-MeO-DIPT [12]. The study also supported the idea that the hallucinogenic activity of 5-MeO-DIPT is mediated through $5-\mathrm{HT}_{1 \mathrm{~A}}$ and $5-\mathrm{HT}_{2 \mathrm{~A}}$ receptors, because 5-MeO-DIPT induced headtwitch response and potentiated forepaw treading induced by 7-(dipropylamino)-5,6,7,8-tetrahydronaphthalen-1-ol (8-OH-DPAT) [13].

Reports by the European Monitoring Centre for Drugs and Drug Addiction (EMCDDA) [14] have indicated an increased abuse of new psychoactive substances (NPS) by adolescents. Exposure to NPS during adolescence may have an impact on brain development and may lead to neuropsychiatric disorders in adulthood. Several studies in adolescent animals showed their greater addictive potential in behavioral studies with cocaine [15] or ethanol [16]. Adolescent rats were also more sensitive than adult animals for cataleptic effect of haloperidol $[17,18]$ or hyperlocomotion induced by morphine [19]. The ontogenetic variations in drug response may result from age-related differences in pharmacokinetics, drug metabolism and excretion rates [20]. It was shown that exposure to ethanol and cocaine during adolescence significantly increased aggressive behavior in adult rodents [16, 21]. Moreover, adults who used marijuana before 15 years of age were 6 times more likely to be dependent on an illicit drug than adults who first used marijuana at 21 years of age or older [22]. The age of first NPS use may be a critical factor for illicit drug use in adulthood. For instance, adults who used marijuana before 15 years of age reported lifetime cocaine and heroin use and nonmedical use of other drugs [22]. Thus, NPS exposure during adolescence may result in severe, long-term and adverse effects in adult life. Unfortunately, there are no direct follow-up human studies in the literature of subjects abusing NPS in adolescence and the effects in adulthood.

The aim of the present study was to find out whether exposure of rats to repeated doses of 5-MeO-DIPT during adolescence [postnatal days (PND) from 30 to 40] may have impact on brain neurotransmission in adulthood. The frontal cortex is the main target of hallucinogens, while the striatum and nucleus accumbens receive strong inputs from the frontal cortex [23]. Thus, 5-MeO-DIPT may stimulate neurons in the frontal cortex and, consequently, may affect striatal and accumbal neurotransmission, as shown by us previously [12]. Therefore, we measured the release of DA, 5-HT and glutamate in the rat striatum, nucleus accumbens and frontal cortex using microdialysis in freely moving adult animals pretreated with 5-MeO-DIPT during adolescence. The comet assay and caspase- 3 activity test were performed to asses 5-MeO-DIPT genotoxic and proapoptotic properties, while the mRNA expression levels of Gpx3 and Sod1 genes were examined to get insight into brain defense system activation by $5-\mathrm{MeO}-\mathrm{DIPT}$. The expression of $5-\mathrm{HT}_{1 \mathrm{~A}}$ and $5-\mathrm{HT}_{2 \mathrm{~A}}$ receptors was measured to determine long-term changes induced by $5-\mathrm{MeO}-\mathrm{DIPT}$ on serotonergic neurotransmission as these receptors are important for hallucinogenic effect [23]. Cell viability was also studied to assess 5-MeO-DIPT cytotoxicity.

\section{Materials and methods}

\section{Animals}

The study was carried out on male Wistar-Han rats (Charles Rivers, Sulzfeld, Germany) weighing 280-300 g. The animals arrived at the vivarium on the 21 st day of age (PND) and were allowed to acclimate until PND 30 (9 days); then they were randomly assigned to control and drug-treated groups. The animals were housed in groups of 5 each in temperature $\left(22 \pm 1^{\circ} \mathrm{C}\right)$ and humidity $(50-60 \%)$ controlled rooms under a $12 \mathrm{~h}$ light/12 $\mathrm{h}$ dark cycle (light phase beginning at 6 a.m.) and had free access to tap water and standard laboratory food (VRF 1; Special Diets Services, Witham, UK).

\section{Drugs and reagents}

5-MeO-DIPT was purchased from Toronto Research Chemicals Inc. (Toronto, Canada). The chemicals used for highperformance liquid chromatography (HPLC) were obtained from Merck (Warsaw, Poland); ketamine hydrochloride and xylazine hydrochloride from Biowet (Puławy, Poland); the chemicals used for the comet assay were from Trevigen (Gaithersburg, MD, USA); Triton from SERVA Electrophoresis (Heidelberg, Germany); the RNeasy Mini Kit 
from Qiagen (Valencia, CA, USA); the high capacity cDNAreverse transcription kit and TaqMan probes for specific gene encoding of HTla, HT2a, Gpx3, Sodl and $\beta$-actin from Life Technologies Applied Biosynthesis (Foster City, CA, USA); probe qPCR Master Mix ( 2 x) from EURx (Gdańsk, Poland); cell culture media including the Dulbecco's modified Eagle's medium (DMEM) and DMEM/F12, heat inactivated fetal bovine serum (FBS), phosphate buffered saline (PBS), trypsin-EDTA, penicillin and streptomycin from Life Technologies (Warsaw, Poland); dimethyl sulfoxide (DMSO), [3-(4,5-dimethyl-2-thiazolyl)-2,5-diphenyl$2 \mathrm{H}$-tetrazolium bromide] (MTT), $o$-phthalaldehyde (OPA) and (+)-methamphetamine from Sigma-Aldrich (Poznań, Poland). Other common chemicals used were of the highest purity commercially available.

\section{Treatment}

Administration of 5-MeO-DIPT started when rats attained PND 30. Rats were injected with 5-MeO-DIPT once daily in a dose of $2.5 \mathrm{mg} / \mathrm{kg}$ for 4 days (PND 30-33) representing the early adolescence period, and after a 3-day break, another 4-day administration started (PND 37-40) representing the middle adolescence period [7]. That pattern of administration was based on drug use by adolescent humans, while the dose selection was based on our behavioural study (Fig. 1). All the experiments were performed when rats reached 90 PND. 5-MeO-DIPT was dissolved in a $0.9 \% \mathrm{NaCl}$ and was administered subcutaneously (s.c.) to prevent abdominal irritation induced by chronic drug administration. The control groups received the corresponding volume of a $0.9 \%$ $\mathrm{NaCl}$ according to the same administration schedule as in the 5-MeO-DIPT-treated animals.

\section{Brain microdialysis}

Animals were anesthetized with ketamine $(75 \mathrm{mg} / \mathrm{kg})$ and xylazine $(10 \mathrm{mg} / \mathrm{kg})$, and vertical microdialysis probes (AgnTho's AB, CNS probes, MAB 4.15.4.Cu; MAB 4.15.3. $\mathrm{Cu}$ and MAB 4.15.2.Cu; AgnTho's, Lidingö, Sweden) were implanted into the striatum, frontal cortex and nucleus accumbens, respectively, using the following coordinates: $\mathrm{AP}+1.8, \mathrm{~L}-3.0, \mathrm{~V}-7.0 ; \mathrm{AP}+2.8, \mathrm{~L}-0.8, \mathrm{~V}-6.0$; $\mathrm{AP}+1.6, \mathrm{~L}-1.1, \mathrm{~V}-8.0$; from the dura, respectively [24]. The number of animals for each treatment group and brain structure was four for the saline/saline group and six for the 5-MeO-DIPT treatment group. On the next day, probe inlets were connected to a syringe pump (BAS, West Lafayette, IN, USA), which delivered artificial cerebrospinal fluid composed of (mM) NaCl 147, $\mathrm{KCl} 2.7, \mathrm{MgCl}_{2} 1.0$ and $\mathrm{CaCl}_{2}$ $1.2 ; \mathrm{pH} 7.4$ at a flow rate of $2 \mu \mathrm{L} / \mathrm{min}$. After $2 \mathrm{~h}$ of washout period, four basal dialysate samples were collected every $20 \mathrm{~min}$; then animals were injected s.c. with 5-MeO-DIPT as indicated in the figure captions and fraction collection continued for $240 \mathrm{~min}$. At the end of the experiment, the rats were sacrificed and their brains were histologically verified for the proper probe placement.

\section{Extracellular concentrations of DA, 5-HT and glutamate}

The DA and 5-HT concentrations in dialysate fractions were analyzed by HPLC with electrochemical detection. Chromatography was performed using an Ultimate 3000 System (Dionex, Sunnyvale, CA, USA), electrochemical detector Coulochem III (model 5300; ESA, Chelmsford, MA, USA) with a 5020 guard cell, a 5014B microdialysis cell and a Hypersil Gold C18 analytical column $(100 \times 3 \mathrm{~mm}$, particle size $3 \mu \mathrm{m}$; Thermo Fischer Scientific, Waltham, MA, USA). The mobile phase was composed of $0.1 \mathrm{M}$ potassium phosphate buffer adjusted to $\mathrm{pH} 3.6,0.5 \mathrm{mM} \mathrm{Na} 2$ EDTA, $16 \mathrm{mg} / \mathrm{L} 1$-octanesulfonic acid sodium salt and $2 \%$ methanol. The flow rate during analysis was set at $0.7 \mathrm{~mL} / \mathrm{min}$. The applied potential of a guard cell was $600 \mathrm{mV}$, while those of microdialysis cells were $E_{1}=-50 \mathrm{mV}, E_{2}=300 \mathrm{mV}$ with a sensitivity set at $50 \mathrm{nA} / \mathrm{V}$. The chromatographic data were processed by the Chromeleon v. 6.80 (Dionex) software package run on a personal computer. The limit of detection of DA and 5-HT in dialysates was $0.002 \mathrm{pg} / 10 \mu \mathrm{L}$ for DA and $0.01 \mathrm{pg} / 10 \mu \mathrm{L}$ for $5-\mathrm{HT}$.

Glutamate levels in the extracellular fluids were measured electrochemically after derivatization with OPA/sulfite
Fig. 1 Schematic illustration of repeated-intermittent 5-methoxy- $N, N$-diisopropyltryptamine (5-MeO-DIPT; $8 \times 2.5 \mathrm{mg} /$ $\mathrm{kg}$ ) administration during adolescence in rats. Grey areas indicate days of administration. $P N D$ postnatal day

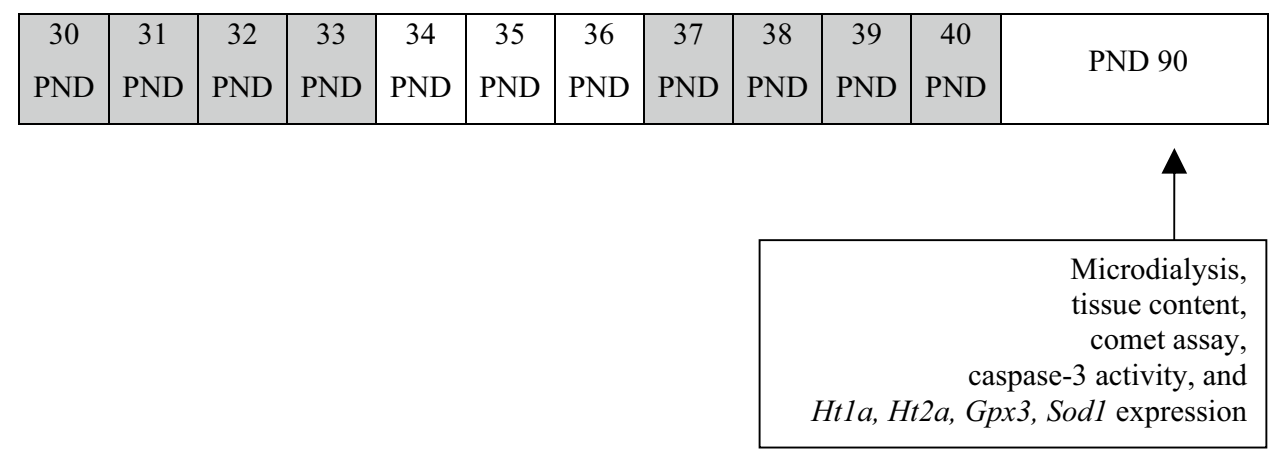


reagent to form isoindole-sulfonate derivative [25]. Chromatography was performed using an Ultimate 3000 pump (Dionex), LC-4B amperometric detector with a cross-flow detector cell (BAS) and an HR-80 column $(80 \times 4.6 \mathrm{~mm}$, particle size $3 \mu \mathrm{m}$; ESA Inc, Chelmsford, MA, USA). The mobile phase consisted of $100 \mathrm{mM}$ monosodium orthophosphate at $\mathrm{pH} 4.6$ and $4 \%$ methanol. The flow rate was $1 \mathrm{~mL} /$ min and the applied potential of a 3-mm glassy carbon electrode was set at $+600 \mathrm{mV}$ at a sensitivity of $5 \mathrm{nA} / \mathrm{V}$. Glutamate-derivative peak was compared with the respective standard and the data were processed using Chromax 2005 (Pol-Lab, Warszawa, Poland) software on a personal computer. The limit of detection of glutamate in dialysates was $0.03 \mathrm{ng} / 10 \mu \mathrm{L}$.

\section{Comet assay}

\section{Preparation of nuclear suspension}

Animals were scarified by decapitation 60 (PND 90) days after termination of drug treatments. Each group (control and 5-MeO-DIPT-treated) comprised six animals. The frontal cortex was separated in anatomical borders. Next, the brain tissue was minced with a surgical scalpel and homogenized in a manual homogenizer with homogenizing solution containing $0.25 \%$ Triton. The homogenate was filtered and centrifuged at $850 \times g$ for $10 \mathrm{~min}$. Thereafter, the supernatant was discarded, while the pellet was resuspended in the same volume of homogenization medium without Triton and centrifuged for $10 \mathrm{~min}$ at $850 \times g$. The sediment was washed once more in the same way and centrifuged at $600 \times g$ for $8 \mathrm{~min}$. The pellet was resuspended in $0.8 \mathrm{~mL}$ of homogenization solution without Triton, mixed with $4.2 \mathrm{~mL}$ of purification medium and centrifuged at $19,000 \times g$ for $45 \mathrm{~min}$. The nuclei were obtained as a transparent sediment at the bottom. The pellet was resuspended in $0.5 \mathrm{~mL}$ of $2.0 \mathrm{M}$ sucrose and was layered over a sucrose gradient (2.6, 2.4 M bottom to top). The gradient was allowed to stand for $3 \mathrm{~h}$ at $0^{\circ} \mathrm{C}$ before use. Fractionation of the nuclei was achieved by centrifugation at $19,000 \times g$ for $45 \mathrm{~min}$.

\section{Analysis of DNA damage}

The nuclei were added to a tube with $200 \mu \mathrm{L}$ of PBS (without $\mathrm{Ca}^{2+}$ and $\mathrm{Mg}^{2+}$ ) and mixed gently. The suspension was mixed with low melting point agarose and transferred immediately onto comet slides. The slides were placed at $4{ }^{\circ} \mathrm{C}$ in the dark for $10 \mathrm{~min}$. Then the slides were immersed in prechilled lysis solution and left at $4^{\circ} \mathrm{C}$ in the dark for $30 \mathrm{~min}$. The buffer was drained, the slides were immersed in alkaline unwinding solution and were left for $45 \mathrm{~min}$ in the dark. In the next step, electrophoresis was run at $21 \mathrm{~V}$ for $30 \mathrm{~min}$. After electrophoresis, the slides were washed first with $\mathrm{H}_{2} \mathrm{O}$, next with $70 \%$ ethanol and dried at $45^{\circ} \mathrm{C}$ for $10 \mathrm{~min}$. The slides were then covered with dye and allowed to dry completely at room temperature in the dark. On the next day, the slides were examined under a fluorescent microscope. DNA damage was presented as the Olive tail moment, which is defined as the product of the tail length and the fraction of total DNA in the tail. Tail moment incorporates a measure of both the detectable size of migrating DNA (reflected in the comet tail length) and the number of damaged pieces (represented by the intensity of DNA staining in the tail). The Olive tail moment is calculated according to the formula: Olive tail moment $=($ tail. mean - head .mean $) \times$ tail $\%$ DNA/100.

\section{Assessment of caspase-3 activities}

Animals were scarified by decapitation ( $n=6$, for control and 5-MeO-DIPT-treated groups) on PND 90. Brains were separated and brain regions were dissected along anatomical borders. The assessment of caspase-3 activity was performed as previously described by [26]. Tissues were homogenized in solution composed of radioimmunoprecipitation assay buffer and protease inhibitors for $20 \mathrm{~min}$ in $15,000 \times \mathrm{g}$. The supernatant was incubated at $37^{\circ} \mathrm{C}$ using a colorimetric substrate preferentially cleaved by caspase-3, i.e., Ac-DEVDpNA ( $N$-acetyl-Asp-Glu-Val-Asp- $p$-nitro-anilide). The levels of $p$-nitroanilide were continuously monitored for $60 \mathrm{~min}$ using a Multimode Microplate Reader Infinite M200PRO (Tecan, Mannedorf, Switzerland). The data were analyzed using Magellan software, normalized to the absorbance of control animals and expressed as a percentage of control \pm standard error of the mean (SEM) from three to four independent experiments. The absorbance of blanks, i.e., no-enzyme controls, was subtracted from each value.

\section{Real-time polymerase chain reaction}

Animals were scarified by decapitation on PND $90(n=6$, for control and 5-MeO-DIPT-treated groups). Brains were isolated and brain regions were dissected along anatomical borders. Total RNA was isolated from the frontal cortex and striatum using the RNeasy Mini Kit (Qiagen) according to the manufacturer's protocol. Real-time polymerase chain reaction (PCR) procedure was adopted from [27]. The quantity of RNA was spectrophotometrically determined at $260 \mathrm{~nm}$ and 260/280 nm (ND/1000 UV/Vis; Tecan NanoDrop, San Jose, CA, USA). Two-step real-time PCR was performed. Both reverse transcription (RT) and the quantitative PCR (qPCR) assays were performed using the CFX 96 Real-Time PCR Detection System (Bio-Rad, Hercules, CA, USA). The RT reaction was performed at a final volume of $20 \mu \mathrm{L}$ using $300 \mathrm{ng}$ of RNA (as a cDNA template) and the High Capacity cDNA Reverse Transcription Kit (Applied 
Biosystems, Waltham, MA, USA), according to the manufacturer's instructions. The products of the RT reaction were amplified using the TaqMan Gene Expression Master Mix containing TaqMan probes (TaqMan, Waltham, MA, USA) as primers specific to the genes encoding HTla, HT2a, Gpx3, Sod 1 and $\beta$-actin. Amplification was performed in a total volume of $20 \mu \mathrm{L}$ of the mixture containing $10 \mu \mathrm{L}$ of the TaqMan Gene Expression Master Mix and $1.0 \mu \mathrm{L}$ of the RT product as the PCR template. The reaction used TaqMan forward and reverse primers and probes labeled with the fluorescent reporter dye fluorescin amidite at the $5^{\prime}$-end and a quenching dye at the $3^{\prime}$-end. The standard qPCR procedures were performed: $2 \mathrm{~min}$ at $50^{\circ} \mathrm{C}$ and $10 \mathrm{~min}$ at $95^{\circ} \mathrm{C}$, followed by 40 cycles of $15 \mathrm{~s}$ at $95{ }^{\circ} \mathrm{C}$ and $1 \mathrm{~min}$ at $60^{\circ} \mathrm{C}$. The threshold value $\left(C_{\mathrm{t}}\right)$ for each sample was set during the exponential phase, and the delta delta $C_{\mathrm{t}}$ method was used for data analysis. The gene encoding $\beta$-actin was used as a reference gene.

\section{Cell cultures}

SH-SY5Y cells purchased from the Leibniz Institute DSMZGerman Collection of Microorganisms and Cell Cultures (DSMZ, Braunschweig, Germany) were cultured in DMEM/ F12 medium supplemented with $10 \%$ FBS and penicillin $(100 \mathrm{U} / \mathrm{mL})$-streptomycin $(100 \mu \mathrm{g} / \mathrm{mL})$ at $37^{\circ} \mathrm{C}$ in a humidified atmosphere enriched with $5 \% \mathrm{CO}_{2}$. Upon reaching $80-90 \%$ confluency, cells were harvested with $0.25 \%$ trypsin in $1 \mathrm{mM}$ EDTA and transferred into 96-well microplates at the density of 10,000 cells/well. Hep G2 cells were also obtained from DSMZ and cultured in DMEM medium supplemented with $10 \%$ FBS and penicillin $(100 \mathrm{U} / \mathrm{mL})$-streptomycin $(100 \mu \mathrm{g} / \mathrm{mL})$ at $37^{\circ} \mathrm{C}$ in a humidified atmosphere enriched with $5 \% \mathrm{CO}_{2}$. Upon reaching 80-90\% confluency, cells were harvested with $0.25 \%$ trypsin in $1 \mathrm{mM}$ EDTA and transferred into 96-well microplates at the density of 5000 cells/well.

\section{Cell viability}

Cell viability and mitochondrial function were assessed through MTT reduction by mitochondrial dehydrogenases. Following overnight incubation, complete culture medium was removed and replaced by fresh medium without FBS and working solutions of the tested compounds, 5-MeODIPT or methamphetamine, were added into microplate wells. After $24-\mathrm{h}$ exposure, a solution of MTT $(0.5 \mathrm{mg} / \mathrm{mL})$ was added and cells were incubated for an additional $3 \mathrm{~h}$ at $37^{\circ} \mathrm{C}$. After aspiration of culture medium, formazan crystals were dissolved in DMSO and absorbance, proportional to the number of cells with intact mitochondria, was measured at $570 \mathrm{~nm}$ using a Bio-Rad microplate reader model 680 (Bio-Rad).

\section{Data analysis}

Repeated measures ANOVA followed by Tukey's post hoc test was performed to analyze drug effect on DA, 5-HT and glutamate release in the rat brain regions. All obtained data were presented as a percent of each basal level assumed to be $100 \%$. DNA damage in the comet assay was tested using one-way ANOVA followed by Tukey's multiple comparison test. One-way ANOVA preceded by the Levene's test of homogeneity of variances was used to determine overall significance in caspase-3 and qPCR experiments. Differences between saline and 5-MeO-DIPT groups were assessed using a post hoc Newman-Keuls test. Cell viability measurements were analyzed using one-way ANOVA followed by Dunnett's post hoc test. The median effective concentration $\left(\mathrm{EC}_{50}\right)$ values were determined using non-linear regression from the plot of $\%$ viability against log dose of complexes added, using GraphPad Prism 6.0 software (GraphPad, San Diego, CA, USA). Differences were considered statistically significant when $p<0.05$. All statistical analyses were carried out using STATISTICA v.10 StatSoft Inc. 1984-2011 (San Francisco, CA, USA) and GraphPad (San Diego, CA, USA).

\section{Results}

\section{Effects of repeated administration of 5-Me0-DIPT during adolescence on the basal extracellular levels of DA, 5-HT and glutamate measured in the adulthood (PND 90)}

The basal extracellular levels of DA in the rat striatum and nucleus accumbens on PND 90 were significantly $(p<0.01)$ decreased after repeated-intermittent 5-MeO-DIPT administration during adolescence. Similarly, the basal extracellular 5-HT levels were significantly $(p<0.01)$ decreased in the rat striatum and nucleus accumbens. In contrast, the basal extracellular level of glutamate was significantly $(p<0.01)$ increased in the rat nucleus accumbens and frontal cortex (Table 1). 
Table 1 Basal levels of dopamine (DA), serotonin (5-HT) and glutamate (GLU) in the rat striatum, nucleus accumbens and frontal cortex after repeated administration of 5-methoxy- $N, N$ diisopropyltryptamine (5-MeODIPT; $8 \times 2.5 \mathrm{mg} / \mathrm{kg}$ ) during adolescence, and measured on PND 90

\begin{tabular}{llll}
\hline Experimental group & $\begin{array}{l}\mathrm{DA}(\mathrm{pg} / 10 \mu \mathrm{L}) \\
\mathrm{Mean} \pm \operatorname{SEM}(n)\end{array}$ & 5-HT $(\mathrm{pg} / 10 \mu \mathrm{L})$ & GLU $(\mathrm{ng} / 10 \mu \mathrm{L})$ \\
\hline Striatum & & & \\
$\quad$ Saline & $5.32 \pm 0.26(16)$ & $0.94 \pm 0.09(16)$ & $1.58 \pm 0.39(16)$ \\
$\quad$ 5-MeO-DIPT in adolescence & $3.26 \pm 0.44(24)^{*}$ & $0.58 \pm 0.04(24)^{*}$ & $1.49 \pm 0.19(24)$ \\
Nucleus accumbens & & & \\
$\quad$ Saline & $2.15 \pm 0.6(16)$ & $0.57 \pm 0.8(16)$ & $1.36 \pm 0.27(16)$ \\
5-MeO-DIPT in adolescence & $0.66 \pm 0.09(24)^{*}$ & $0.44 \pm 0.03(24)^{*}$ & $3.22 \pm 0.28(24)^{*}$ \\
Frontal cortex & & & \\
$\quad$ Saline & $0.93 \pm 0.16(16)$ & $0.48 \pm 0.05(16)$ & $1.04 \pm 0.24(16)$ \\
5-MeO-DIPT in adolescence & $0.96 \pm 0.11(24)$ & $0.46 \pm 0.40(24)$ & $2.98 \pm 0.9(24)^{*}$ \\
\hline
\end{tabular}

Data are the mean \pm standard error of the mean (SEM). ${ }^{*} p<0.01$ vs. respective control (one-way ANOVA and Tukey's post hoc test)

\section{Effects of repeated administration of 5-MeO-DIPT during adolescence on extracellular levels of DA, 5-HT and glutamate measured in the adulthood (PND 90) in the rat striatum, nucleus accumbens and frontal cortex}

\section{Striatum}

5 -MeO-DIPT given repeatedly $(2.5 \mathrm{mg} / \mathrm{kg} / \mathrm{day})$ for 8 days during adolescence significantly decreased the extracellular DA level in the rat striatum as measured on PND 90 in response to the challenge dose of $2.5 \mathrm{mg} / \mathrm{kg}$ (Fig. 2a). The same 5-MeO-DIPT dose markedly increased the extracellular DA level in saline-treated animals (Fig. 2a). Repeated measures ANOVA showed significant effects of treatment groups $\left(F_{2,11}=2677, p<0.0001\right)$, sampling period $\left(F_{11,121}=82, p<0.0001\right)$ and the interaction between treatment groups and sampling period $\left(F_{22,121}=34, p<0.0002\right)$.

The extracellular 5-HT levels in the rat striatum were increased by the challenge 5-MeO-DIPT dose of $2.5 \mathrm{mg} / \mathrm{kg}$ both in saline- and 5-MeO-DIPT-treated groups during adolescence; however, response to 5-MeO-DIPT was stronger in saline-treated animals (Fig. 2b). Repeated measures ANOVA showed significant effects of treatment groups $\left(F_{2,12}=488\right.$, $p<0.0001)$, sampling period $\left(F_{11,132}=32, p<0.0001\right)$ and the interaction between treatment groups and sampling period $\left(F_{22,132}=11, p<0.0001\right)$.

The extracellular glutamate levels were increased to a similar extent by the challenge 5-MeO-DIPT dose at $2.5 \mathrm{mg} / \mathrm{kg}$ both in saline- and 5-MeO-DIPT-treated groups during adolescence (Fig. 2c). Repeated measures ANOVA showed significant effects of treatment groups $\left(F_{2,10}=915\right.$, $p<0.0001)$, sampling period $\left(F_{11,110}=110, p<0.0001\right)$ and the interaction between treatment groups and sampling period $\left(F_{22,110}=180, p<0.0001\right)$.

The total effects expressed as areas under the curve (AUCs) shown in Fig. 2d reflect the responses to 5-MeO-DIPT resulting in striatal DA, 5-HT and glutamate release presented as time-course curves.

\section{Nucleus accumbens}

The responses to the challenge dose of 5-MeO-DIPT $(2.5 \mathrm{mg} / \mathrm{kg})$ of the extracellular DA level were similar both in saline- and 5-MeO-DIPT-treated animals during adolescence (Fig. 3a). Repeated measures ANOVA showed significant effects of treatment groups $\left(F_{2,11}=1765, p<0.0001\right)$, sampling period $\left(F_{11,121}=46, p<0.0001\right)$ and the interaction between treatment groups and sampling period $\left(F_{22,121}=18\right.$, $p<0.0001$ ).

The challenge dose of 5 -MeO-DIPT $(2.5 \mathrm{mg} / \mathrm{kg})$ increased the extracellular 5-HT levels in the rat nucleus accumbens similarly both in saline- and 5-MeO-DIPTtreated animals during adolescence (Fig. 3b). Repeated measures ANOVA showed significant effects of treatment groups $\left(F_{2,11}=303, p<0.0001\right)$, sampling period $\left(F_{11,121}=43, p<0.0001\right)$ and the interaction between treatment groups and sampling period $\left(F_{22,121}=18, p<0.0001\right)$.

The extracellular glutamate levels in the nucleus accumbens were increased by the challenge dose of 5-MeO-DIPT $(2.5 \mathrm{mg} / \mathrm{kg})$ more potently in saline- than in 5-MeO-DIPTtreated animals during adolescence (Fig. 3c). Repeated measures ANOVA showed significant effects of treatment groups $\left(F_{2,10}=5330, p<0.0001\right)$, sampling period $\left(F_{11,110}=128, p<0.0001\right)$ and the interaction between treatment groups and sampling period $\left(F_{22,110}=97, p<0.0001\right)$.

Total effects expressed as AUCs shown in Fig. 3d reflect the responses to 5-MeO-DIPT in accumbal DA, 5-HT and glutamate release presented as time-course curves.

\section{Frontal cortex}

The challenge dose of 5-MeO-DIPT $(2.5 \mathrm{mg} / \mathrm{kg})$ increased extracellular DA levels in the rat frontal cortex more potently 
Fig. 2 Effects of a challenge dose of 5-MeO-DIPT $(2.5 \mathrm{mg} /$ $\mathrm{kg}$ ) on extracellular levels of dopamine (DA), serotonin (5-HT) and glutamate (GLU) measured in adulthood (PND 90) in the striatum (STR) in rats treated with $5-\mathrm{MeO}$ DIPT $(8 \times 2.5 \mathrm{mg} / \mathrm{kg})$ during adolescence. a-c show each time-course, while $\mathbf{d}$ shows the total effects expressed as the area under the curve (AUC) of the percent of each basal level. Values are the mean \pm standard error of the mean (SEM) $[n=4$ animals for saline/saline and 6 animals per experimental group (saline/5-MeO-DIPT and 5-MeO-DIPT $8 \times 2.5 / 5-\mathrm{MeO}-$ DIPT)]. The time of drug injection is indicated with an arrow. ${ }^{*} p<0.001 \mathrm{vs}$. sal/sal group; ${ }^{\wedge} p<0.001$ vs. sal/5-MeO-DIPT group (time-course: repeated measures ANOVA and Tukey's post hoc test; total effect: oneway ANOVA and Tuckey's post hoc test)
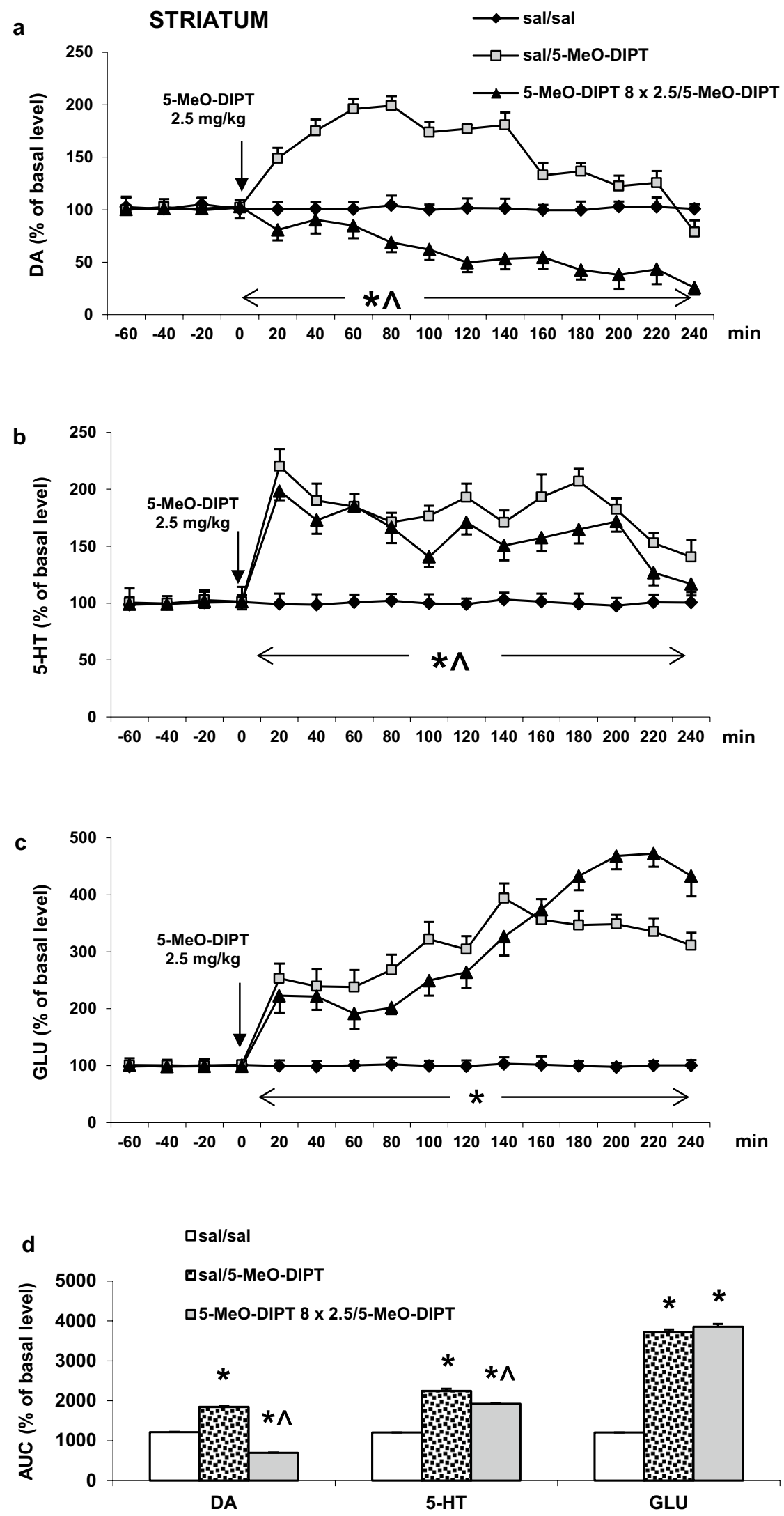
Fig. 3 Effects of a challenge dose of 5-MeO-DIPT $(2.5 \mathrm{mg} /$ $\mathrm{kg}$ ) on extracellular levels of DA, 5-HT and GLU measured in adulthood (PND 90) in the nucleus accumbens (NAS) in rats treated with 5-MeO-DIPT $(8 \times 2.5 \mathrm{mg} / \mathrm{kg})$ during adolescence. a-c show each timecourse, while $\mathbf{d}$ shows the total effects expressed as the AUC of the percent of each basal level. Values are the mean \pm SEM $[n=4$ animals for saline/saline and 6 animals per experimental group (saline/5-MeO-DIPT and 5 -MeO-DIPT $8 \times 2.5 / 5-\mathrm{MeO}-$ DIPT)]. The time of drug injection is indicated with an arrow. $* p<0.001$ vs. sal/sal group; ${ }^{\wedge} p<0.001$ vs. sal/5-MeO-DIPT group (time-course: repeated measures ANOVA and Tukey's post hoc test; total effect: oneway ANOVA and Tukey's post hoc test)
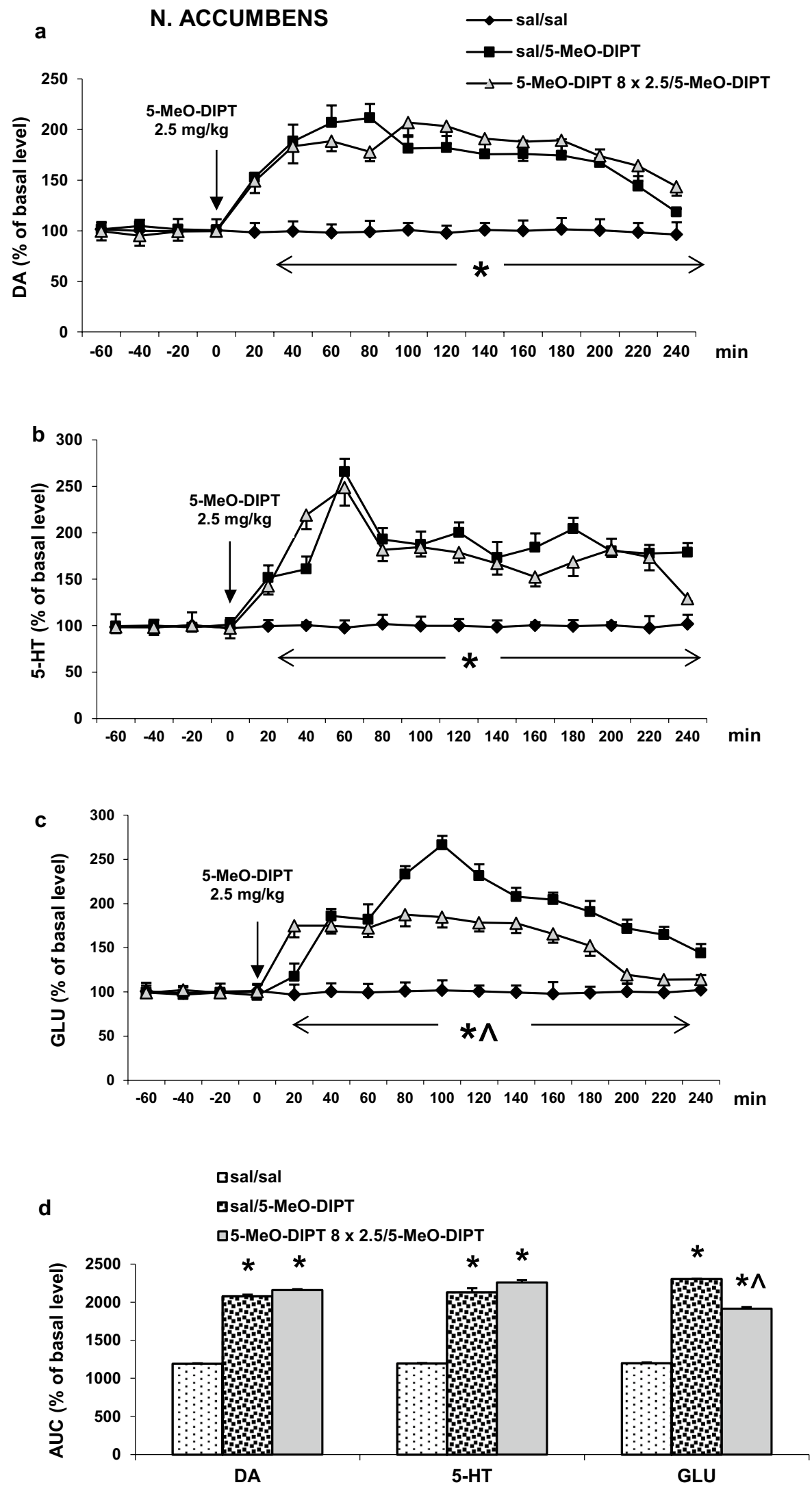
Fig. 4 Effects of a challenge dose of 5-MeO-DIPT $(2.5 \mathrm{mg} /$ $\mathrm{kg}$ ) on extracellular levels of DA, 5-HT and GLU measured in adulthood (PND 90) in the frontal cortex (FCX) in rats treated with $5-\mathrm{MeO}-$ DIPT $(8 \times 2.5 \mathrm{mg} / \mathrm{kg})$ during adolescence. a-c show the timecourses, while $\mathbf{d}$ shows the total effects expressed as the AUC of the percent of each basal level. Values are the mean \pm SEM $[n=4$ animals for saline/saline and 6 animals per experimental group (saline/5-MeO-DIPT and 5 -MeO-DIPT $8 \times 2.5 / 5-\mathrm{MeO}-$ DIPT)]. The time of drug injection is indicated with an arrow. $* p<0.001$ vs. sal/sal group; ${ }^{\wedge} p<0.001$ vs. sal/5-MeO-DIPT group (time-course: repeated measures ANOVA and Tukey's post hoc test; total effect: oneway ANOVA and Tukey's post hoc test)
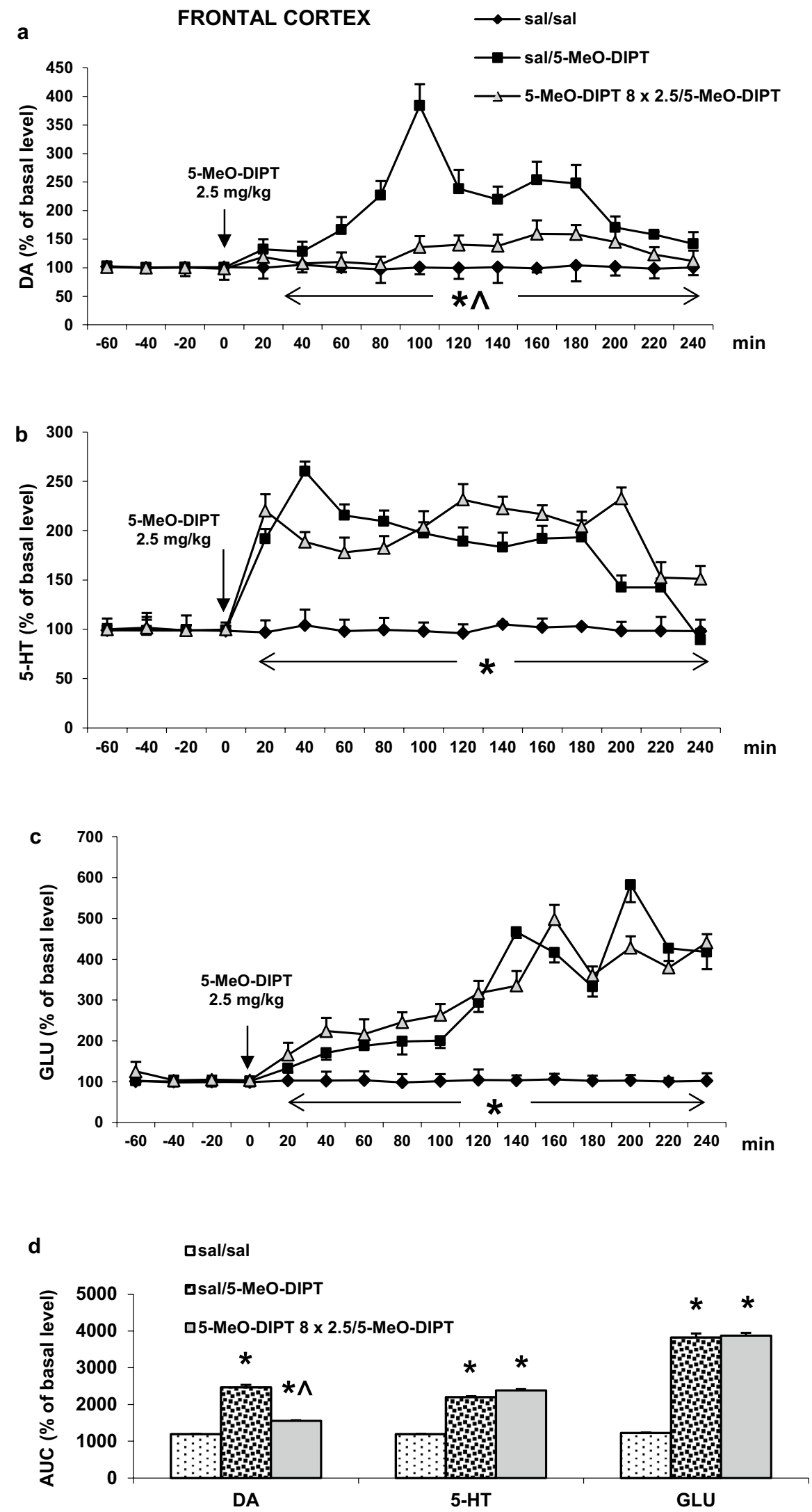
in animals treated with saline only than in those treated with 5-MeO-DIPT during adolescence (Fig. 4a). Repeated measures ANOVA showed significant effects of treatment groups $\left(F_{2,12}=405, p<0.0001\right)$, sampling period $\left(F_{11,132}=84\right.$, $p<0.0001)$ and the interaction between treatment groups and sampling period $\left(F_{22,132}=59, p<0.0001\right)$.

The increase in extracellular 5-HT level in the rat frontal cortex induced by the challenge dose of 5-MeO-DIPT $(2.5 \mathrm{mg} / \mathrm{kg})$ was similar in saline- and 5-MeO-DIPT-treated animals during adolescence (Fig. 4b). Repeated measures ANOVA showed significant effects of treatment groups $\left(F_{2,12}=446, p<0.0001\right)$, sampling period $\left(F_{11,132}=31\right.$, $p<0.0001)$ and the interaction between treatment groups and sampling period $\left(F_{22,132}=24, p<0.0001\right)$.

The extracellular glutamate levels were increased by the challenge dose of $5-\mathrm{MeO}$-DIPT $(2.5 \mathrm{mg} / \mathrm{kg})$ to a similar extent in saline- and 5-MeO-DIPT-treated animals during adolescence (Fig. 4c). Repeated measures ANOVA showed significant effects of treatment groups $\left(F_{2,11}=318\right.$, $p<0.0001)$, sampling period $\left(F_{11,121}=88, p<0.0001\right)$ and the interaction between treatment groups and sampling period $\left(F_{22,121}=27, p<0.0001\right)$.

The total effects expressed as AUC shown in Fig. 4d reflect the responses to 5-MeO-DIPT resulting in cortical DA, 5-HT and glutamate release presented as time-course curves.

\section{Effects of single and repeated administration of 5-MeO-DIPT during adolescence on oxidative DNA damage in the rat cortex}

5-MeO-DIPT given repeatedly $(2.5 \mathrm{mg} / \mathrm{kg} /$ day) for 8 days during adolescence produced DNA damage shown as a percent of the Olive tail moment in the rat cortex on PND 90 (Fig. 5). However, the damage was smaller in animals

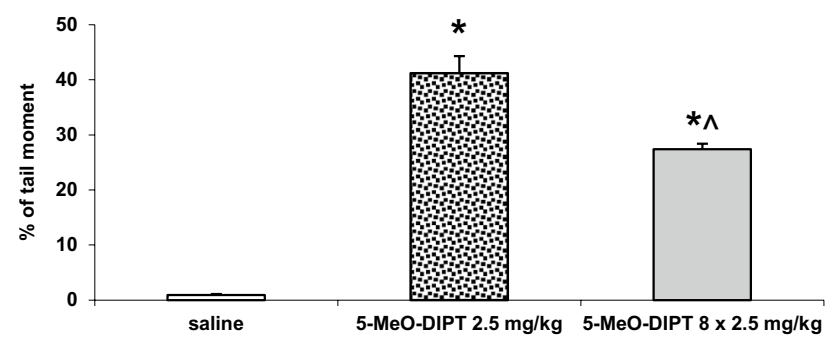

Fig. 5 Effects of a single $(2.5 \mathrm{mg} / \mathrm{kg})$ and repeated $(8 \times 2.5 \mathrm{mg} /$ $\mathrm{kg}$ ) administration of 5-MeO-DIPT during adolescence on the oxidative damage of DNA in nuclei from the rat cortex. Data are the mean \pm SEM ( $n=6$ animals per group) and represent an Olive tail moment. Loss of DNA integrity persisted until 60 days after drug administration. ${ }^{*} p<0.01$ in comparison to control group, ${ }^{\wedge} p<0.01$ repeated vs. single administration (one-way ANOVA and Tukey's post hoc test) repeatedly treated with 5-MeO-DIPT than in animals which received only a single dose $(2.5 \mathrm{mg} / \mathrm{kg})$ of $5-\mathrm{MeO}-\mathrm{DIPT}$.

\section{Effects of repeated administration of 5-Me0-DIPT during adolescence on caspase- 3 activities in the striatum, nucleus accumbens and frontal cortex of adult rats}

Repeated 5-MeO-DIPT administrations during adolescence significantly decreased caspase- 3 activity in the nucleus accumbens to $66 \%$ of the control level $(p<0.01)$, increased its level to $156 \%$ of the control level in the frontal cortex $(p<0.01)$, but had no effect on caspase- 3 activity in the striatum as measured on PND 90 (Fig. 6).

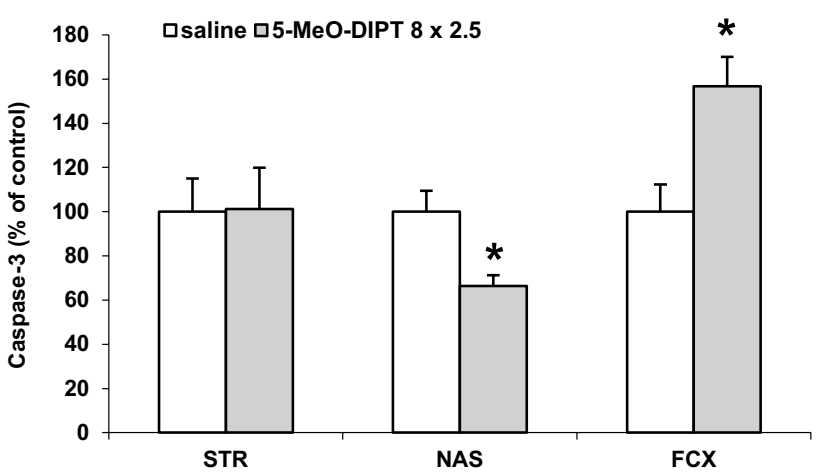

Fig. 6 Effects of repeated 5-MeO-DIPT $(8 \times 2.5 \mathrm{mg} / \mathrm{kg})$ administration during adolescence on caspase- 3 activity measured in the rat STR, NAS and FCX in adulthood (PND 90). The results are the mean \pm SEM ( $n=6$ animals per group) and are presented as a percent of the saline treated group. ${ }^{*} p<0.01$ in comparison to the saline group (one-way ANOVA preceded by the Leven's test of homogeneity of variances)

\section{Effects of repeated administration of 5-MeO-DIPT during adolescence on the mRNA expression levels for Htr1 $a$ and Htr2a genes, and Gpx3 and Sod 1 genes in the rat frontal cortex and striatum, respectively}

Repeated 5-MeO-DIPT administration during adolescence significantly $(p<0.05)$ decreased mRNA expression levels of Htrla and Htr2a genes in comparison to the respective controls when measured on PND 90 in the rat frontal cortex (Fig. 7a). Data were normalized to those of $\beta$-actin.

Repeated 5-MeO-DIPT administration during adolescence significantly $(p<0.05)$ increased mRNA expression levels of Gpx3 and Sod1 genes in comparison to the respective controls as measured on PND 90 in the rat striatum (Fig. 7b). Data were normalized to those of $\beta$-actin. 
a

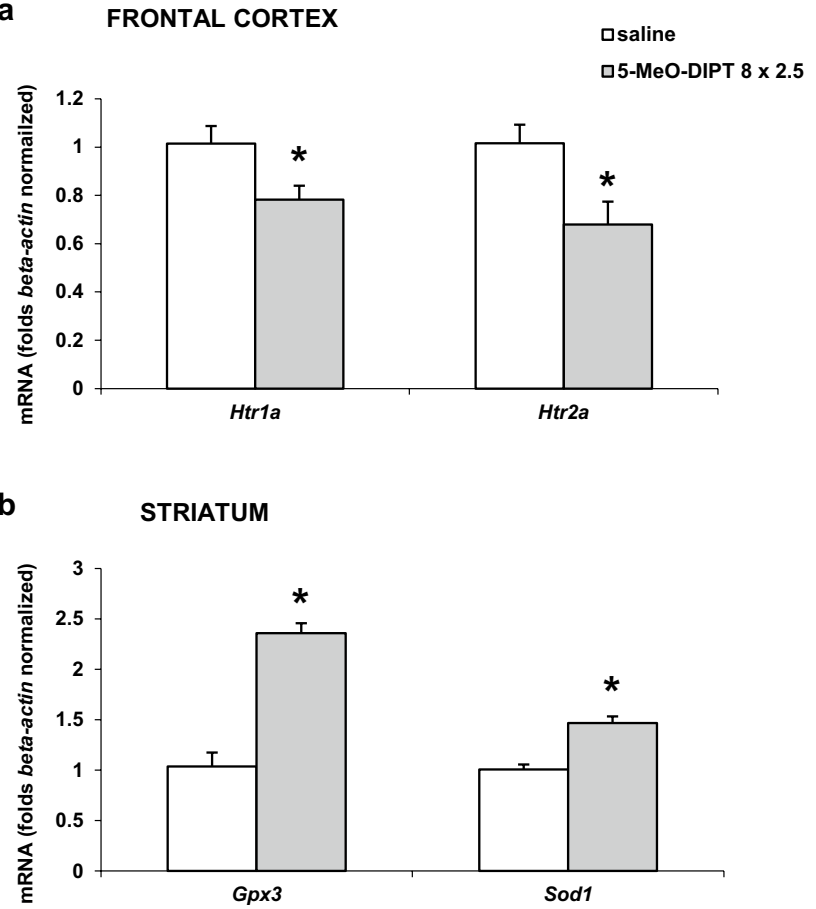

Fig. 7 Effects of repeated 5-MeO-DIPT $(8 \times 2.5 \mathrm{mg} / \mathrm{kg})$ administration during adolescence on the mRNA expression levels of Htrla and Htr2a genes (a) and Gpx3 and Sodl genes (b) measured in adulthood (PND 90) in the rat FCX and STR, respectively. The open bars show the saline control, and the gray bars the results with the repeated administration of $5-\mathrm{MeO}-\mathrm{DIPT}(8 \times 2.5 \mathrm{mg} / \mathrm{kg})$ during adolescence. Each bar represents the mean \pm SEM of three independent experiments from six rats. The number of replicates for each experiment ranged from two to three. ${ }^{*} p<0.05$ vs. saline group (one-way ANOVA preceded by the Levene's test of homogeneity of variances)

\section{Effects of 5-MeO-DIPT and methamphetamine on viability of neuroblastoma SH-SY5Y and Hep G2 cells}

Cultured SH-SY5Y and Hep G2 cell lines were challenged with 5-MeO-DIPT (0.1-2 $\mathrm{mM})$ for $24 \mathrm{~h}$ and cell viability was measured by mitochondrial activities. Exposure of both cell lines to 5-MeO-DIPT resulted in a concentrationdependent decrease of their viability with statistical significance starting at $0.5 \mathrm{mM}$ for both cell lines. The maximal effect was observed at $2 \mathrm{mM}$, i.e., decrease in survival of SH-SY5Y and Hep G2 cells to 15 and $11 \%$ of control values, respectively (Fig. 8a). The calculated $\mathrm{EC}_{50}$ values were $0.8 \mathrm{mM}$ for SH-SY5Y cells and $0.6 \mathrm{mM}$ for Hep G2 cells.

Methamphetamine, used as a reference compound, induced a mark decrease in cell viability. However, the cytotoxic effect of methamphetamine was much less pronounced than that of 5-MeO-DIPT and statistical significance was reached only at $2.0 \mathrm{mM}$, where 24 -h exposure led to a decrease of cell survival to 70 and $67 \%$ of control values, for Hep G2 and SH-SY5Y cells, respectively (Fig. 8b).

\section{Discussion}

5-MeO-DIPT given repeatedly to animals during adolescence changed response of adult animals to the challenge dose of the drug. It decreased response of DA neurons in the striatum (Fig. 2a) and frontal cortex (Fig. 4a). The response of 5-HT and glutamatergic neurons was also decreased in the striatum (Fig. 2b, c) and nucleus accumbens (Fig. 3b, c), respectively. The basal extracellular levels of DA and 5-HT were decreased in the striatum and nucleus accumbens after repeated 5-MeO-DIPT administration during adolescence. In contrast, the basal extracellular glutamate level was markedly increased in the nucleus accumbens and frontal cortex (Table 1). The damage of cortical DNA (Fig. 5), increased expression of antioxidant enzymes (Fig. 7b), and changes
Fig. 8 Effects of 5-MeO-DIPT (a) and methamphetamine (b) on viability of neuroblastoma SH-SY5Y and Hep G2 cells. The cells were incubated with the tested compounds for $24 \mathrm{~h}$ and cell viability and mitochondrial function was analyzed by the MTT test. Data are the mean \pm SEM of $10-12$ values per group and are expressed as a percentage of the respective control. $* p<0.05, * * p<0.01$, $* * * p<0.001$ vs. control (oneway ANOVA followed by Dunnett's post hoc test) a

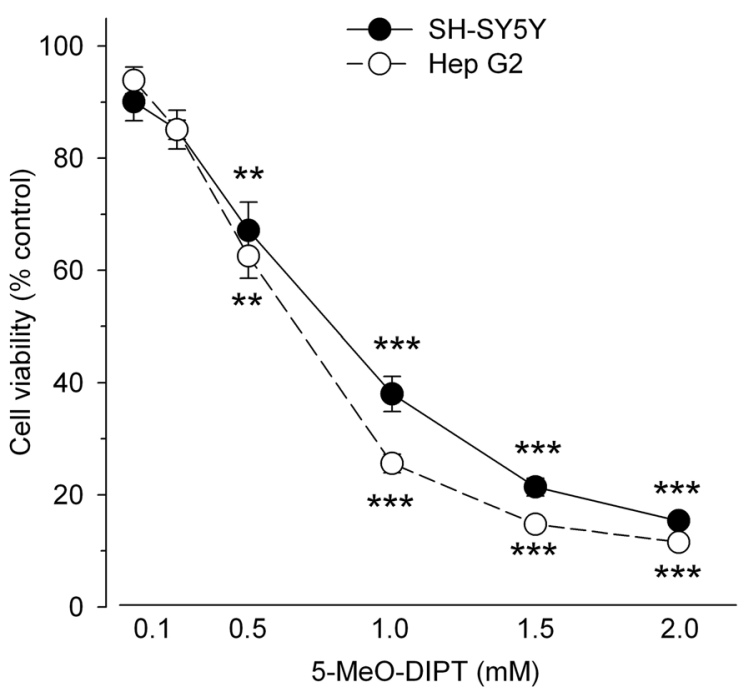

b

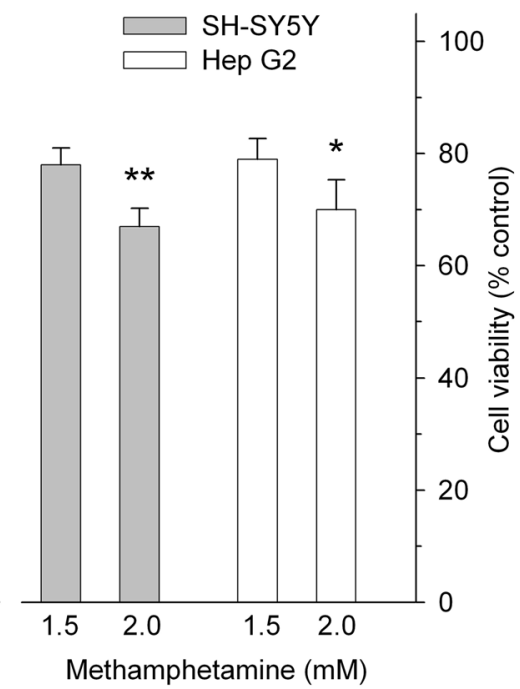


in caspase-3 activity (Fig. 6) were also observed in adult animals after repeated 5-MeO-DIPT administration during adolescence. Furthermore, decreased expression of 5-HT $1 \mathrm{~A}$ and 5-HT ${ }_{2 \mathrm{~A}}$ receptors was observed (Fig. 7a). Marked cytotoxicity of 5-MeO-DIPT in the SH-SY5Y and Hep G2 cell line was found (Fig. 8a).

In our study, we observed changes in basal extracellular levels of neurotransmitters which persisted until adulthood in animals pretreated with 5-MeO-DIPT. These changes were not identical for all neurotransmitters and all studied brain regions. Namely, basal DA level was decreased in the striatum and nucleus accumbens; similarly basal 5-HT level was also decreased in the same brain regions. On the other hand, basal glutamate level was increased in the frontal cortex and nucleus accumbens (Table 1). It may be hypothesized that repeated-intermittent administration of 5-MeO-DIPT caused deficit in DA and 5-HT nerve endings in subcortical brain regions. In contrast, we observed activation of excitatory neurons in the frontal cortex and nucleus accumbens resulting in outflow of glutamate from glutamatergic neuronal cells or astrocytes by repeated-intermittent administration of 5-MeO-DIPT. The overstimulation of cortical glutamatergic cells could underlie the excitotoxicity leading to oxidative damage of neuronal cells shown by single- and double-strand DNA breaks and activation of caspase-3 activity. It indicates development of oxidative stress which elicits impairment of glutamatergic neurons in the cortex. As a consequence of glutamatergic cell impairment, stimulatory input to the ventral tegmental area (VTA), substantia nigra and nuclei raphe could be weaker [28, 29], which resulted in decreased basal activities of DA and 5-HT neurons in subcortical regions.

Another issue is the altered neuronal response to the challenge dose of 5-MeO-DIPT, e.g., weaker responses of DA neurons in the striatum (Fig. 2a) and frontal cortex (Fig. 4a), 5-HT neurons in striatum (Fig. 2b) and glutamatergic neurons in the nucleus accumbens (Fig. 3c). These results may be explained by the decreased expression of cortical 5- $\mathrm{HT}_{1 \mathrm{~A}}$ and 5- $\mathrm{HT}_{2 \mathrm{~A}}$ receptors observed in our study. $5-\mathrm{HT}_{2 \mathrm{~A}}$ receptors are located on cortical pyramidal cells as well as on the DA cell bodies in the VTA, where they regulate activities of pyramidal cells and mesolimbic and mesocortical DA pathways, respectively [28, 30-33]. 5- $\mathrm{HT}_{1 \mathrm{~A}}$ receptors, besides the somatodendritic location in the dorsal raphe nucleus, are also found postsynaptically in the limbic and cortical regions $[34,35]$. The decreased expression of $5-\mathrm{HT}_{2 \mathrm{~A}}$ receptors in pyramidal cells of adult animals shown in our study after repeated treatment with 5-MeO-DIPT during adolescence may be the cause of weaker response of 5-HT and DA neurons to the challenge dose of this drug. Similarly, we observed the decreased expression of cortical 5-HT $1 \mathrm{~A}$ receptors in adult animals after repeated treatment with 5-MeO-DIPT during adolescence (Fig. 7a). 5- $\mathrm{HT}_{1 \mathrm{~A}}$ receptor stimulation leads to inhibition of neuronal activity [34]. These receptors were shown to be located on GABAergic interneurons in the frontal cortex [36]. Thus, the possibility of decreased density as shown by attenuated expression of inhibitory $5-\mathrm{HT}_{1 \mathrm{~A}}$ receptors and subsequent increase in GABA levels may result in weaker responses of DA neurons in the striatum (Fig. 2a) and frontal cortex (Fig. 4a) and 5-HT neurons in the striatum (Fig. 2b) of adult animals to the challenge dose of 5-MeO-DIPT.

The attenuated response of glutamatergic neurons in the nucleus accumbens (Fig. 3c) may be related to damage of the cortico-accumbal glutamatergic pathway or weaker direct stimulation of these efferents by $5-\mathrm{MeO}-\mathrm{DIPT}$ via $5-\mathrm{HT}_{2 \mathrm{~A}}$ receptors, the cortical expression of which was decreased (Fig. 7a). Interestingly, the damage of nuclear DNA in animals treated repeatedly with 5-MeO-DIPT in adolescence was less pronounced than in animals which received a single dose of the drug (Fig. 5). This effect suggests a possible activation of the enzymatic defense systems during repeated administration of 5-MeO-DIPT. In the striatum of adult animals, the caspase-3 activity was unchanged (Fig. 6), but expression of Gpx3 and $\operatorname{Sod} 1$ was increased (Fig. 7b). It is likely that the enzymatic defense system efficiently protected striatal cells from apoptotic cell death in response to 5-MeO-DIPT given during adolescence [37]. The response of cells to oxidative stress may involve post-translational modifications of many proteins and their functions. Caspase-3 may be, for instance, regulated by glutathionylation resulting from the oxidation of the major cellular antioxidant glutathione (GSH). The oxidized form of GSH, glutathione disulfide, was shown to inhibit caspase-3 activity in HL-60 cells [38]. This mechanism may underlie the inhibition of caspase- 3 in the nucleus accumbens by $5-\mathrm{MeO}-\mathrm{DIPT}$. The issue of defense system activation by 5-MeO-DIPT needs further investigation.

Cytotoxic properties of 5-MeO-DIPT were shown by its effect on cell viability in SH-SY5Y and Hep G2 cell lines. We found that in the presence of $2 \mathrm{mM}$ concentration of 5 -MeO-DIPT, only ca. $15 \%$ of cells survived, while in the same concentration of methamphetamine, more than $70 \%$ of cells survived in both cell lines (Fig. 8). These data indicate a potent direct cytotoxicity of 5-MeO-DIPT, even stronger than cytotoxicity produced by methamphetamine. The mechanism of a potent cytotoxic effect of 5-MeO-DIPT is not clear and needs further studies.

Adolescence is a very important period for brain development and there are strong evidences demonstrating that abnormalities during neurodevelopment, including exposure to drugs of abuse, may lead to neuropsychiatric disorders. Case reports showed marked 5-MeO-DIPT toxicity and indicated long-lasting changes in brain function reflected by hallucinogen-persisting perception disorder development or prolonged delusional state $[39,40]$. Our study confirms 
the neurotoxic properties of 5-MeO-DIPT found in animal experimental models.

\section{Conclusions}

5-MeO-DIPT exposure during adolescence resulted in a marked impact of this substance on DA, 5-HT and glutamate neurotransmission. 5-MeO-DIPT induced oxidative stress which was manifested by oxidative damage of nuclear DNA, activation of apoptotic signals and increased expression of antioxidant enzymes. Moreover, a dramatic in vitro cytotoxicity of 5-MeO-DIPT was observed.

Acknowledgements Karolina Noworyta-Sokołowska is a holder of a scholarship from the KNOW sponsored by the Ministry of Science and Higher Education, Republic of Poland. The study was supported by grant no. 2013/09/B/NZ7/04104 from the National Science Center (Poland) and statutory activity of the Institute of Pharmacology Polish Academy of Sciences.

\section{Compliance with ethical standards}

Conflict of interest The authors declare that they have no conflict of interest.

Ethical approval All applicable international, national and institutional guidelines for the care and use of animals were followed. All animal experiments were conducted in strict accordance with European regulations concerning experiments on animals (directive 2010/63/EU on the protection of animals used for scientific purposes). The experimental protocols were approved by the Local Ethics Commission for Experimentation on Animals (permit number: 1274/2015). This article does not contain any studies with human participants performed by any of the authors.

Open Access This article is distributed under the terms of the Creative Commons Attribution 4.0 International License (http://creativeco mmons.org/licenses/by/4.0/), which permits unrestricted use, distribution, and reproduction in any medium, provided you give appropriate credit to the original author(s) and the source, provide a link to the Creative Commons license, and indicate if changes were made.

\section{References}

1. Shulgin AT, Carter MF (1980) $N, N$-Diisopropyltryptamine (DIPT) and 5-methoxy- $N, N$-diisopropyltryptamine (5-MeO-DIPT). Two orally active tryptamine analogs with CNS activity. Commun Psychopharmacol 4:363-369 (PMID 6949674)

2. DEA (2013) 5-Methoxy- $N, N$-diisopropyttryptamine (street names: Foxy, or Foxy methoxy). http://www.deadiversion.usdoj.gov/ drug_chem_info/5meodipt.pdf. Accessed 28 Feb 2016

3. Sogawa C, Sogawa N, Tagawa J, Fujino A, Ohyama K, Asanuma M, Funada M, Kitayama S (2007) 5-Methoxy- $N, N$-diisopropyltryptamine (Foxy), a selective and high affinity inhibitor of serotonin transporter. Toxicol Lett 170:75-82. https://doi. org/10.1016/j.toxlet.2007.02.007

4. Nagai F, Nonaka R, Satoh K, Kamimura H (2007) The effects of non-medically used psychoactive drugs on monoamine neurotransmission in rat brain. Eur J Pharmacol 559:132-137. https://doi.org/10.1016/j.ejphar.2006.11.075

5. Fantegrossi WE, Harrington AW, Kiessel CL, Eckler JR, Rabin RA, Winter JC, Coop A, Rice KC, Woods JH (2006) Hallucinogen-like actions of 5-methoxy- $N, N$-diisopropyltryptamine in mice and rats. Pharmacol Biochem Behav 83:122-129. https:// doi.org/10.1016/j.pbb.2005.12.015

6. Blough BE, Landavazo A, Decker AM, Partilla JS, Baumann MH, Rothman RB (2014) Interaction of psychoactive tryptamines with biogenic amine transporters and serotonin receptor subtypes. Psychopharmacology 231:4135-4144. https ://doi.org/10.1007/s00213-014-3557-7

7. Compton DM, Selinger MC, Westman E, Otero P (2012) Modification of serial pattern learning by designer tryptamine exposure during adolescence: comparison with damage to the dorsal hippocampus or prefrontal cortex. Int J Psychol Behav Sci 2:263-273. https://doi.org/10.5923/j.ijpbs.20120206.10

8. Compton DM, Dietrich KL, Selinger MC, Testa EK (2011) 5-Methoxy- $N, N$-di(iso)propyltryptamine hydrochloride (Foxy)induced cognitive deficits in rat after exposure in adolescence. Physiol Behav 103:203-209. https://doi.org/10.1016/j.physb eh.2011.01.021

9. Compton DM, Selinger MC, Westman E, Otero P (2011) Differentiation of MDMA or 5-MeO-DIPT induced cognitive deficits in rat following adolescent exposure. Psychol Neurosci 4:157-169. https://doi.org/10.3922/j.psns.2011.1.018

10. Tittarelli R, Mannocchi G, Pantano F, Romolo FS (2015) Recreational use, analysis and toxicity of tryptamines. Curr Neuropharmacol 13:26-46. https://doi.org/10.2174/1570159X1366614 1210222409

11. Smolinske SC, Rastogi R, Schenkel S (2005) Foxy methoxy: a new drug of abuse. J Med Toxicol 1:23-25 (PMID 18072099)

12. Noworyta-Sokołowska K, Kamińska K, Kreiner G, Rogóż Z, Gołembiowska K (2016) Neurotoxic effects of 5-MeO-DIPT: a psychoactive tryptamine derivative in rats. Neurotox Res 30:606-619. https://doi.org/10.1007/s12640-016-9654-0

13. Larsson LG, Rényi L, Ross SB, Svensson B, Angeby-Möller K (1990) Different effects on the responses of functional preand postsynaptic $5-\mathrm{HT}_{1 \mathrm{~A}}$ receptors by repeated treatment of rats with the $5-\mathrm{HT}_{1 \mathrm{~A}}$ receptor agonist 8-OH-DPAT. Neuropharmacology 29:85-91. https://doi.org/10.1016/0028-3908(90)90047 $-\mathrm{U}$

14. EMCDDA (2017) European drug report 2017: trends and developments. http://www.emcdda.europa.eu/edr2017_en. Accessed 18 Aug 2017

15. Estroff TW, Schwartz RH, Hoffmann NG (1989) Adolescent cocaine abuse. Addictive potential, behavioral and psychiatric effects. Clin Pediatr (Phila) 28:550-555. https://doi. org/10.1177/000992288902801201

16. Spear LP (2000) The adolescent brain and age-related behavioral manifestations. Neurosci Biobehav Rev 24:417-463. https://doi. org/10.1016/S0149-7634(00)00014-2

17. Campbell A, Baldessarini R, Teicher M (1988) Decreasing sensitivity to neuroleptic agents in developing rats; evidence for a pharmacodynamic factor. Psychopharmacology 94:46-51. https ://doi.org/10.1007/BF00735879

18. Spear LP, Shalaby IA, Brick J (1980) Chronic administration of haloperidol during development: behavioral and psychopharmacological effects. Psychopharmacology 70:47-58 (PMID 6775334)

19. Spear LP, Horowitz GP, Lipovsky J (1982) Altered behavioral responsivity to morphine during the periadolescent period in rats. Behav Brain Res 4:279-288. https://doi.org/10.1016/01664328(82)90005-5

20. Hein K (1987) The use of therapeutics in adolescence. J Adolesc Health Care 8:8-35. https://doi.org/10.1016/0197-0070(87)90244 $-0$ 
21. Salimov RM, McBride WJ, McKinzie DL, Lumeng L, Li T-K (1996) Effects of ethanol consumption by adolescent alcoholpreferring $\mathrm{P}$ rats on subsequent behavioral performance in the cross-maze and slip funnel tests. Alcohol 13:297-300. https://doi. org/10.1016/0741-8329(95)02060-8

22. Substance Abuse and Mental Health Services Administration (SAMHSA) (2003) Results from the 2002 national survey on drug use and health: national findings. SAMHSA Office of Applied Studies. Rockville, pp 1-274. https://files.eric.ed.gov/fulltext/ ED479833.pdf. Accessed 18 Aug 2017

23. Halberstadt AL (2015) Recent advances in the neuropsychopharmacology of serotonergic hallucinogens. Behav Brain Res 277:99-120. https://doi.org/10.1016/j.bbr.2014.07.016

24. Paxinos G, Watson C (1998) The rat brain in stereotaxic coordinates. Academic Press, San Diego

25. Rowley HL, Martin KF, Marsden CA (1995) Determination of in vivo amino acid neurotransmitters by high-performance liquid chromatography with $o$-phthalaldehyde-sulphite derivatization. J Neurosci Methods 57:93-99. https://doi.org/10.1016/01650270(94)00132-Z

26. Kajta M, Makarewicz D, Ziemińska E, Jantas D, Domin H, Lasoń W, Kutner A, Łazarewicz JW (2009) Neuroprotection by co-treatment and post-treating with calcitriol following the ischemic and excitotoxic insult in vivo and in vitro. Neurochem Int 55:265-274. https://doi.org/10.1016/j.neuint.2009.03.010

27. Wnuk A, Rzemieniec J, Lasoń W, Krzeptowski W, Kajta M (2017) Apoptosis induced by the UV filter benzophenone-3 in mouse neuronal cells is mediated via attenuation of Ero/Ppary and stimulation of Er/Gpr30 signaling. Mol Neurobiol. https:// doi.org/10.1007/s12035-017-0480-z

28. Di Mateo V, Di Giovanni G, Pierucci M, Esposito E (2008) Serotonin control of central dopaminergic function: focus in in vivo microdialysis studies. Prog Brain Res 172:7-44. https://doi. org/10.1016/S0079-6123(08)00902-3

29. Soiza-Reilly M, Commons KG (2011) Glutamatergic drive of the dorsal raphe nucleus. J Chem Neuroanat 41:247-255. https://doi. org/10.1016/j.jchemneu.2011.04.004

30. Aghajanian GK, Marek GJ (1997) Serotonin induces excitatory postsynaptic potentials in apical dendrites of neocortical pyramidal cells. Neuropharmacology 36:589-599. https://doi. org/10.1016/S0028-3908(97)00051-8

31. Aghajanian GK, Marek GJ (1999) Serotonin and hallucinogens. Neuropsychopharmacology 21:16S-23S. https://doi.org/10.1016/ S0893-133X(98)00135-3
32. Béique J-C, Imad M, Mladenovic L, Gingrich JA, Andrade R (2007) Mechanism of the 5-hydroxytryptamine 2A receptormediated facilitation of synaptic activity in prefrontal cortex. Proc Natl Acad Sci USA 104:9870-9875. https://doi.org/10.1073/ pnas.0700436104

33. Puig MV, Celada P, Díaz-Mataix L, Artigas F (2003) In vivo modulation of the activity of pyramidal neurons in the rat medial prefrontal cortex by $5-\mathrm{HT}_{2 \mathrm{~A}}$ receptors: relationship to thalamocortical afferents. Cereb Cortex 13:870-882. https://doi.org/10.1093/ cercor/13.8.870

34. Hamon M, Gozlan H, El Mestikawy S, Emerit MB, Bolaños F, Schechter L (1990) The central 5-HT 1 A receptors: pharmacological, biochemical, functional, and regulatory properties. Ann N Y Acad Sci 600:114-129. https://doi.org/10.1111/j.1749-6632.1990. tb16877.x (discussion 129-131)

35. Pazos A, Palacios JM (1985) Quantitative autoradiographic mapping of serotonin receptors in the rat brain. I. Serotonin-1 receptors. Brain Res 346:205-230. https://doi.org/10.1016/00068993(85)90856-X

36. Leiser SC, Li Y, Pehrson AL, Dale E, Smagin G, Sanchez C (2015) Serotonergic regulation of prefrontal cortical circuitries involved in cognitive processing: a review of individual 5-HT receptor mechanisms and concerted effects of 5-HT receptors exemplified by the multimodal antidepressant vortioxetine. ACS Chem Neurosci 6:970-986. https://doi.org/10.1021/cn500340j

37. López-Arnau R, Martinez-Clemente J, Rodrigo T, Pubill D, Camarasa J, Escubedo E (2015) Neuronal changes and oxidative stress in adolescent rats after repeated exposure to mephedrone. Toxicol Applied Pharmacol 286:27-35. https://doi.org/10.1016/j. taap.2015.03.015

38. Huang Z, Pinto JT, Deng H, Richie JP (2008) Inhibition of caspase-3 activity and activation by protein glutathionylation. Biochem Pharmacol 75:2234-2244. https://doi.org/10.1016/j. bcp.2008.02.026

39. Fuse-Nagase Y, Nishikawa T (2013) Prolonged delusional state triggered by repeated ingestion of aromatic liquid in a past 5-methoxy- $N, N$-diisopropyltryptamine abuser. Addict Sci Clin Pract 8:9. https://doi.org/10.1186/1940-0640-8-9

40. Ikeda A, Sekiguchi K, Fujita K, Yamadera H, Koga Y (2005) 5-Methoxy- $N, N$-diisopropyltryptamine-induced flashbacks. Am J Psychiatry 162:815. https://doi.org/10.1176/appi.ajp.162.4.815 